\title{
An Overview of the Relationship Between Agricultural Biological Disasters and Meteorological Conditions in Yunnan
}

\author{
Guihua Zhou \\ Disaster Prevention Association of Yunnan Province \\ Kunming,China \\ km-zgh@163.com

\section{云南农业生物灾害概况与气象条件关系综述}

周桂华

云南省灾害防御协会

昆明 650224, 中国

km-zgh@163.com

\begin{abstract}
The meteorological conditions that determine the agricultural harmful organisms occur as a key factor in the popular departures from the inter-ministerial changes,often affected when biological disasters from occurring. Yunnan agricultural meteorological disasters occur frequently. There are many different types of constraints on the development of agriculture in an important factor. Yunnan Province of agricultural biological disaster including pests and weeds, mouse, etc., frequent changes in the quantity and variety and technical nature, is very difficult to defend. The characteristics of Yunnan's three-dimensional climate determine that such disasters have strong regional and annual differences. Select this year 1971-2015 Yunnan agricultural biological part of disaster-related data, the Yunnan agricultural biological profiles, aggression with causes of aggression indicators and geographic distribution of laws have been summarized and agricultural meteorological disasters, climate change impacts on agricultural biological the impact of disasters and their prevention and control measures in such research.
\end{abstract}

Keywords-Yunnan agricultural biological disasters; overview; meteorological conditions review

摘要一气象条件是决定农业有害生物发生流行的关键因 素, 气象要素年际间的异常变化, 常影响当年生物灾害的发 生等级。云南立体气候的特点决定了这类灾害具有较强的地 区性和年度间的差异性。文章选取 1971-2015 年云南农业生 物灾害部分相关数据, 对云南农业生物概况、致灾机理与成 因, 致灾指标, 时空分布规律进行了阐述。着重对生物灾害 发生、发展及演变与气象条件的关系做了分析与研究, 提出 了相应的防治措施。

\section{I. 引言}

农业生物灾害种类繁多，危害严重的即达 1300 多 种。据联合国粮农组织（FA0）统计, 8 种主要农作物 （水稻、小麦、大麦、玉米、马铃薯、大豆、棉花和咖 啡）因为有害动物、病原菌和杂草危害造成的损失分别 为 $15.6 \% 、 13.3 \%$ 和 $13.2 \%$, 合计为 $42.1 \%$ 。如 果再加上收获后病虫害造成的损失 9\% 20\%，全世界 农业有害生物所导致的农作物损失总计达 $48 \%$ 左右。我
国随着经济全球化进程的加快, 国际旅游、交流的迅猛 发展, 外来入侵生物的问题日趋加重, 异常天气的发生 频率增高，加上有不少地区种植制度不合理和管理粗 放, 导致农作物重大病虫灾害此起彼伏, 频繁成灾。迄 今，全国农作物有害生物发生面积约 3.5 亿 hm2 / 次, 防治后仍损失粮食 500 万 $\mathrm{t}$ 、棉花 30 万 $\mathrm{t}$ 、油料作物 93 万 $\mathrm{t}$ 、其他作物 1084 万 $\mathrm{t}[1]$ 。因此, 加强农业有害生 物综合治理的实践任务重大。同时, 随着生活水平的提 高, 人们对农副产品不仅要求能解决温饱问题, 而且还 要求优质、安全、有保健等功能。这就对有害生物治理 的教学和实践提出了更高的要求。

农业生物灾害, 受气候条件的制约[2]。云南生物灾 害发生频繁、面复杂的基本特点对农业生物灾害发生造 成了严重影响。从总的情况看, 云南省大多数地方的气 候温和, 雨量适度, 素有动植物王国之称, 有害生物的 种类多, 常见的生物灾害, 几乎应有尽有[3]。更由于山 川河谷将大地割裂在小气候不同的区域, 各地的生产条 件及生产技术的差异, 再加上植保工作的开展不平衡, 形成了较大的生物灾害的插花发生的现象。云南省农业 生物灾害除具有常发性之外, 还存在着一些生物灾害在 目前尚未弄清原因就突然爆发成灾的情况。气象要素年 际间的异常变化, 常影响当年生物灾害的发生等级。如 严重影响我国农业生产的重大迁飞性害虫：草地螟、稻 纵卷叶螟、白背飞闽、褐飞蛙等，在其适迁期，降落地 连续降雨是促成苦虫降落的重要条件, 迁入降落虫量过 大时，常导致暴发性灾害发生[4]。

长期以来, 云南农作物病虫害与气象关系的基础研究 不够, 对农作物病虫害发生发展规律与气象关系研究不 多，在生物灾害预测、可持续治理上没有大的突破。目 前的研究主要集中在某种单一生物灾害的特点、呈现规 律等的一些总结归纳，对单一生物灾害的时空发生规律 和预测、气象等级预报研究以及单一生物灾害发生原因 和防治等方面有一些研究。但对云南整个生物灾害特点 和规律、与气候变化关系, 包括极端气候条件影响等领 域尚未涉及。本文系统总结了云南生物灾害特点和规 
律, 试图从云南大气候背景环境, 包括季节变化, 极端 气候条件对生物灾害的影响等方面做一些研究分析, 并 提出相应的防治措施。

\section{II. 云南农业生物灾害概况}

近几年来，云南省气候异常，极端气象灾害频发，再 加上随着农业生产的发展、耕作制度的复杂多样，为病 虫草鼠害提供了极有利的生存消长环境, 因而灾害有日 趋严重的现象。

\section{1 发生面积及损失情况}

1971-1975 年间，生物灾害的发生面积为年均 1220 khm2；1976-1980 年间达到年均 $1220 \mathrm{khm} 2 ； 1976-1980$ 年间达到年均 $1280 \mathrm{khm} 2$; 1981-1985 年间平均发生面 积达 $2180 \mathrm{khm} 2$; 1986-1990 期间上升到 $3660 \mathrm{khm} 2$ 。 1991-1995 年间上升到 $4243 \mathrm{khm} 2 ， 1996-2000$ 年间上升 到 $7171.29 \mathrm{khm} 2 ， 2001-2005$ 年间上升到 34 791.77khm2，2006-2010 年间为 $8531.83 \mathrm{khm} 2,2011-$ 2015 年间为 $9482.76 \mathrm{khm} 2$, 若以 1990 年发生面积 4890 $\mathrm{khm} 2$ 与 2015 年的 $100506.7 \mathrm{khm} 2$ 对比, 25 年间发生灾 害的面积增加了 4.2 倍，呈直线上升趋势。1991-2015 年 间达到平均 $7473.8 \mathrm{khm} 2$ （表 1, 据王景来, 杨子汉 《云南自然灾害与减灾研究 1990-2000》）。

\section{2 主要农作物病虫害}

云南总计有害生物 8 183种，构成威胁并造成损失的 给有 300 余种。据全省第二次病虫草害的普查结果，在 云南有记录的农作物病害有 677 种, 其中包括真菌病害 546 种、细菌病害37种、病毒病害（包括类菌原体）50 种、线虫病 20 种、藻类 9 种、寄生植物 5 种、毛毡病 2 种、地衣2种、生理病害6种; 对生产上危害严重具有经 济价值的病害有 60 余种。有记录的昆虫更多，包括昆虫 纲的28目、298科、6 707种（不含卫生害虫），还有不 属昆虫纲的有 3 纲、 6 目、29科、143种。记录的杂草有 99 科 800 种, 其中稻田杂草 98 种、小春地杂草35种、大 春旱地杂草 90 种、坝区旱地杂草 298 种、荒坡杂草 264 种、植物寄生性杂草 10 种、另有检疫性杂草3种、恶性 杂草2种。主要农作物的病害有稻瘟病、稻白叶枯病、 稻条纹叶枯病；小麦条锈病、杆锈病历、叶锈病；玉米 丝黑穗病、大斑病; 虫豆锈病、根腐病、赤斑病、细菌 性枯萎病以及蔬菜、果树的多种病害。主要虫害有稻

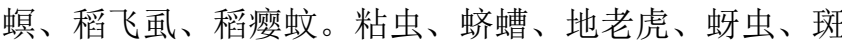
潜蝇; 以及蔬菜、果树的多种病虫害。随着生产力水平 的提高和商品经济的发展, 例如稲翁瘟病、小麦白粉 病、稻飞闽等现在则普遍上升，严重威胁农业生产 $[5]$ 。

\section{3主要病虫害损失统计}

相关研究和生产实践表明，农作物病虫害的发生、发 展和流行须同时具备以下 3 个条件: (1)有可供病虫滋生 和食用的寄主植物; (2)病虫本身处在对作物有危害能力 的发育阶段; (3)有使病虫进一步发展曼延的适宜环境条 件。其中气象条件是决定病虫害发生流行的关键因素。 几乎所有大范围流行性、爆发性、毁灭性的农作物重大 病虫害的发生、发展和流行都与气象条件密切相关, 或
表 1. 1971-2015 年云南省病虫草鼠害发生面积及损失情况 $W$

\begin{tabular}{|c|c|c|}
\hline 年份 & 发生面积/khm2 & 产量损失/万 $\mathbf{t}$ \\
\hline 1971 & 884 & 26.7 \\
\hline 1972 & 1486 & 34.1 \\
\hline 1973 & 1225 & 42.7 \\
\hline 1974 & 1104 & 27.8 \\
\hline 1975 & 1390 & 34.0 \\
\hline 1976 & 1893 & 45.0 \\
\hline 1977 & 2347 & 59.3 \\
\hline 1978 & 1464 & 46.5 \\
\hline 1979 & 1795 & 38.9 \\
\hline 1980 & 1921 & --- \\
\hline 1981 & 1551 & 13.0 \\
\hline 1982 & 2262 & 17.4 \\
\hline 1983 & 1646 & 12.4 \\
\hline 1984 & 2764 & 20.0 \\
\hline 1985 & 2706 & 33.6 \\
\hline 1986 & 2080 & 16.6 \\
\hline 1987 & 2468 & 10 \\
\hline 1988 & 4708 & 15.0 \\
\hline 1989 & 4167 & 15.7 \\
\hline 1990 & 4891 & 26.7 \\
\hline 1991 & 4864 & 25.4 \\
\hline 1992 & 5825 & 105.0 \\
\hline 1993 & 2084 & 11.9 \\
\hline 1994 & 5623 & 36.0 \\
\hline 1995 & 2819 & 36.2 \\
\hline 1996 & 6721.41 & 40.68 \\
\hline 1997 & 7008.64 & 44.59 \\
\hline 1998 & 7510.03 & 46.10 \\
\hline 1999 & 7676.05 & 46.11 \\
\hline 2000 & 6940.01 & 27.70 \\
\hline 2001 & 6890.86 & 57.78 \\
\hline 2002 & 6599.13 & 62.53 \\
\hline 2003 & 6855.73 & 56.01 \\
\hline 2004 & 6982.00 & 60.55 \\
\hline 2005 & 7464.05 & 107.20 \\
\hline 2006 & 7083.28 & 56.21 \\
\hline 2007 & 8569.67 & 30.35 \\
\hline 2008 & 10633.32 & 71.51 \\
\hline 2009 & 7594.29 & 71.03 \\
\hline 2010 & 8778.61 & 85.64 \\
\hline 2011 & 6816.01 & 49.09 \\
\hline 2012 & 10261.52 & 82.64 \\
\hline 2013 & 10178.67 & 78.22 \\
\hline 2014 & 10106.95 & 74.64 \\
\hline 2015 & 10050.67 & 34.69 \\
\hline
\end{tabular}


与气象灾害相伴发生, 一旦遇到灾变气候, 就会大面积 发生流行成灾 $[6]$ 。

生物灾害发生程度分为 5 等。轻发生: 病虫密度达 到防治指标, 产量损失率在 $5 \%$ 以下; 中偏轻发生: 病虫 密度较低, 但超过防治指标, 产量损失一般为 $5 \%$ $10 \%$; 中等发生: 病虫密度较大, 产量损失率为 $10 \%$ 20\%; 中 偏重发生：病虫密度大，产量损失为 $20 \%$ $30 \%$; 大发 生: 病虫密度很大，产量损失率

在 30\%以上。表 2 统计了 1971-2015 年粮食作物主要 病虫发生面积。（注：此表据田长伟、韩建成的资料换 算）

从表 2 可以看出, 11 种病虫害中有呈主要上升趋势 的有: 稻飞闽、稻粘虫、稻瘟病、䖯豆蚜虫、玉米叶斑 病, 其中, 稻粘虫在 1982 年达到 $660 \mathrm{khm} 2$, 是常年水 平的 6 倍。玉米螟呈比较明显的下降趋势。

\section{4 云南农业生物灾害特点}

（1）种类多、地区性和年度间的差异明显

由于生物灾害属于次生灾害的范畴, 它的发生危害 既受自然气候的影响，又受耕作制度、作物布局、品种 安排、栽培技术等因素的制约; 而生物种群的地理分布
取决于自然自然气候的区划, 其数量的变动则受气候 (自然因素) 和耕作栽培（人为因素）的双重影响。例 如就大的趋势看, 一般干旱高温的年景虫灾发生较重, 而多雨低温年成则病害流行突出; 又如在调整结构、改 革耕作栽培制度时, 病虫草害都会发生显著的变化。因 此, 在云南 “立体气候” 的条件下, 生物灾害具有较强 的地区性和年度间的差异性，而表现为变动性较大和插 花性的特点。

\section{（2）耕作条件变化和检疫性病虫传入}

生产力水平的提高、商品经济的发的展和集约化经 营也影响到生物灾害的发生。在提高和改进生产技术的 条件下, 过去一些低产条件发生的病虫, 如稻赤枯病、 食根叶蛱、铁甲虫、玉米大小斑病等发生危害都在相应 地减少, 而一些高产条件发生的病虫, 如稻瘟病、小麦 白粉病、稻飞風等则普遍上升。严重威胁生产，尤其基 地大面积连作生产的蔬菜、果树病虫草害都很突出。随 着种子、苗木、农产品的异地交换, 10 多种检疫性病虫 传入, 有些种类已成为普遍性的常发病虫, 对生产构成 极大威胁。

\section{（3）环境适应性强}

有害生物在自然选择、生物竞争的过程中，增加了自

表 2. 1971-2015 年粮食作物主要病虫害发生面积

\begin{tabular}{|c|c|c|c|c|c|c|c|c|c|c|c|}
\hline \multirow{2}{*}{ 年份 } & \multicolumn{11}{|c|}{ 粮食作物主要病虫害发生面积/khm2 } \\
\hline & 稻瘟病 & 稻蛽虫 & 稻粘虫 & 稻飞虫 & 小麦锈病 & 小麦白粉病 & 小麦蚜虫 & 玉米蛽 & 玉米丝黑穗病 & 玉米叶斑病 & 蚕豆蚜虫 \\
\hline 1971 & 246 & 139.3 & 28.3 & 13.7 & 30.1 & 1.7 & 13.9 & 180 & 126.7 & 4.5 & 7.8 \\
\hline 1972 & 28.7 & 245.3 & 215.3 & 21.7 & 45.6 & 4.1 & 18.1 & 218.7 & 60 & 3.7 & 12.7 \\
\hline 1973 & 18.9 & 130.1 & 103.5 & 24.9 & 60.8 & 23.9 & 13.1 & 181.6 & 181.0 & 4.0 & 13.6 \\
\hline 1974 & 66.7 & 102.5 & 31.5 & 30.9 & 57.2 & 18 & 13.8 & 204.5 & 186.5 & 1.9 & 14.2 \\
\hline 1975 & 21.7 & 136.5 & 56.0 & 180.0 & 20.3 & 28.1 & 17.5 & 212.9 & 206.7 & 19.8 & 16.7 \\
\hline 1976 & 33.6 & 201.0 & 111.9 & 233.3 & 23.7 & 34.3 & 133.3 & 230.7 & 186.7 & 1.20 & 66.7 \\
\hline 1977 & 40.0 & 236.0 & 48.5 & 266.7 & 67.2 & 110.0 & 200.3 & 170.9 & 233.3 & 50.7 & 133.3 \\
\hline 1978 & 66.3 & 190.0 & 35.7 & 73.1 & 51.0 & 57.4 & 115.4 & 131.0 & 87.8 & 57.7 & 30.0 \\
\hline 1979 & 66.7 & 191.0 & 148.7 & 111.9 & 63.9 & 31.3 & 226.0 & 97.6 & 67.1 & 90.0 & 74.30 \\
\hline 1980 & 63.5 & 138.4 & 51.0 & 105.7 & 133.3 & 61.3 & 160.0 & 71.6 & 118.8 & 176.8 & 80.0 \\
\hline 1981 & 104.5 & 201.5 & 74.6 & 244.3 & 168.7 & 129.8 & 90.0 & 69.30 & & 111.1 & 62.4 \\
\hline 1982 & 92.3 & 303.0 & 664.4 & 280.2 & 128.6 & 132.2 & 145.9 & 139.0 & 125.1 & 133.4 & 129.5 \\
\hline 1983 & 85.6 & 230.0 & 181.8 & 230.4 & 126.8 & 101.9 & 144.5 & 72.3 & 77.2 & 84.0 & 108.6 \\
\hline 1984 & 164.7 & 200.5 & 286.0 & 204.3 & 31.3 & 29.8 & 98.7 & 65.0 & 67.6 & 100.5 & 93.2 \\
\hline 1985 & 191.6 & 190.4 & 66.1 & 282.1 & 44.1 & 48.6 & 103.4 & 63.9 & 71.3 & 178.5 & 190.0 \\
\hline 1986 & 112.0 & 164.8 & 64.4 & 185.6 & 23.1 & 28.5 & 66.2 & 52.6 & 48.1 & 130.6 & 80.6 \\
\hline 1987 & 57.0 & 110.5 & 186.4 & 151.3 & 39.5 & 38.7 & 112.8 & 54.0 & 57.6 & 97.2 & 92.0 \\
\hline 1988 & 73.0 & 151.0 & 210.2 & 160.1 & 35.5 & 39.6 & 119.6 & 109.4 & 64.1 & 115.7 & 130.1 \\
\hline 1989 & 81.4 & 157.3 & 100.0 & 291.9 & 47.4 & 59.8 & 129.6 & 121.8 & 84.9 & 120.7 & 198.7 \\
\hline 1990 & 129.6 & 173.6 & 184.9 & 223.9 & 116.4 & 80.7 & 144.0 & 97.3 & 73.8 & 141.3 & 154.3 \\
\hline 1991 & 74.7 & 152.4 & 115.0 & 244.0 & 107.5 & 88.9 & 168.9 & 119.2 & 64.6 & 158.2 & 115.1 \\
\hline 1992 & 93.3 & 145.7 & 53.7 & 232.3 & 101.7 & 115.2 & 177.3 & 120.9 & 47.7 & 136.5 & 106.6 \\
\hline 1993 & 83.3 & 81.3 & 70.9 & 114.8 & 81.0 & 101.2 & 195.9 & 206.0 & 30.0 & 69.0 & 121.3 \\
\hline 1994 & 157.2 & 151.5 & 38.3 & 240.6 & 85.4 & 88.1 & 218.1 & 105.0 & 43.0 & 137.9 & 121.3 \\
\hline 1995 & 189.3 & 317.4 & 60.2 & 518.7 & 69.9 & 108.4 & 206.6 & 112.2 & 40.7 & 135.2 & 129.4 \\
\hline
\end{tabular}


身对环境的抗力或适应性, 使人们在防治技术上增加了 难度。如云南的小麦条锈病菌、其流行有一定的周期 性, 防病手段主要是推行抗病品种, 当人们大面积采用 了抵抗当时的锈菌小种时, 锈病的发生就得到控制, 发 病面积很快回落; 随着时间的推移, 锈菌的生理小种亦 随之发生变异而产生新的小种; 经过繁殖增长到一定程 度时, 锈病又复发流行起来。而且, 这些新小种的致病 力和毒性远比原有的小种为强。病情加重, 流行广泛。 稻瘟病和其它一些病害也有类似的规律。在虫害方面, 则表现为大虫或叶面害虫容易活，而许多小虫或潜居性 害虫难治而呈上升趋势。病害方面还有细菌性、病毒类 等超小微生物的危害日益加重。新病虫和抗性病虫危害 严重, 农业生物灾害面临许多新的顽敌, 也是灾情发展 的新动向。

\section{III. 生物灾害与气象条件关系研究探讨}

\section{1 云南主要生物灾害与气候关系}

大气、气候条件直接影响和制约着生物灾害的发生流 行; 温度、湿度、降雨、风速、风向等气象要素可直接 影响病害的发生、发展、侵染和流行, 影响害虫、害鼠 和杂草的发育、繁殖、越冬、分布、迁移和适应等[7]。 研究表明: 气象条件是决定有害生物发生流行的关键因 素;几乎所有大范围流行性、暴发性、毁灭性的农作物重 大病虫害的发生、发展和流行都与气象条件密切相关, 或与气象灾害相伴发生; 一旦遇到灾变气候, 就会大面积 发生流行成灾。有害生物种群暴发与调节的理论或假说 之一, 认为有利的气候变化直接(如暖冬)或间接(如初级 发生流行成灾。有害生物种群暴发与调节的理论或假说 之一，认为有利的气候变化直接(如暖冬)或间接(如初级 生产力增加)地提高了有害生物种群的繁殖力和存活力, 引起有害生物数量暴发 [8]。见表 3 。

\section{2 致灾机理}

\subsection{1 气候变暖对生物灾害的影响}

气候变暖与生物灾害的发生有明显的相关性[9]。

1. 对农作物虫害的影响。

(1) 适生区拓宽、发育速率提高。气候变暖加快了 害虫体内生理过程、适生期和适生区得到延长和拓宽, 发育速率、生殖力都得到加快和增强[10]。如 CO2 浓度 升高可能增大蛾类幼虫的取食量; 提高蚜虫的生殖力; 昆虫基于碳源和氮源的化学防御物质含量降低; 不利于 寄生性天敌的寄生和生长发育; 降低转基因抗虫作物毒 素含量; 降低杀虫剂的化学防治效果。

（2）发生频率增加、种群增长加快。气候变暖增加 了害虫的存活率, 尤其是越冬基数, 直接导致始见期、 迁飞期、种群高峰期提前, 世代数增加, 发生程度加 重, 暴发周期缩短[11]。加速种群增长,扩大害虫分布范 围,有利于迁飞害虫的发生和为害, 使作物、害虫、天敌 等三级营养层物候协调关系出现断裂,可使害虫或潜在害 虫失控而猖獗[12]。
（3）生理变异、种群间关系改变。气候变暖导致有 害生物种群的基因组成发生变化。为适应气候变暖, 昆 虫体内某些染色体或基因发生变异以增加自身的耐热 性, 且变异频率与温度增加幅度呈正相关[13]。气候变 暖使高温适生昆虫的种群密度增加, 物种适热性差异导 致有害生物与寄主植物同步性改变, 从而影响力昆虫的 正常取食并进一步影响其种群发展[14]。

2. 对农作物病害的影响。

(1)改变寄主作物的生理和抗病性。例如,UV-B 辐射 增强或高浓度 CO2 条件使病原菌繁殖力提高, 可能加速 病原菌种群的进化, 导致病原菌迅速克服寄主作物的抗病 性; 冬季气温升高将降低病原菌越冬死亡率, 春季气温升 高将使越冬病原提前萌发和侵染、扩散, 高湿是病原真菌 和细菌萌发和浸染的必要条件,而干旱通过

促进喜旱传毒害虫可导致作物病毒病的猖獗发生 [15]。

(2)温度、降水和极端气候变化频繁将影响病害流 行。

(3)病害地理分布范围变化将改变病害组成结构[16]。

3.对农田杂草的影响。

(1)气温升高使杂草分布向北延伸和向高海拔延伸。

(2)具有 C4 光合路径的杂草具有更强的适应和进化潜 能, 可能比作物更快利用新的适宜生境, 扩张其分布范围, 致使新环境的作物面临新的杂草为害[17]。

(3)CO2 浓度升高将有利于植物的光合作用,但其对农 作物和杂草的影响可能并非相等, 通常会增强杂草的相对 竞争力[18]。

(4)CO2 浓度升高使化学农药的使用量增大,除草剂的 防效可能明显降低。

\subsection{2 云南气候变化与生物灾害特点}

从云南的气象灾害对农业生产的影响来看, 影响最大 的是旱灾和霜冻。八月低温, 虽然不是每年都出现, 但 对滇中和北部的水稻有严重的威胁[19]。

\section{(1) 干早}

干旱，是影响全省农业生产最大的主要自然灾害 [20]。云南干旱灾害出现频繁, 除受地形影响外, 大气 环流是造成干旱的主要原因[21]。云南和全国一样处于 夏雨冬旱的季风气候区域里, 由于季风气候的雨量分布 不均和季风的异常变动, 这就不但在年际变化上常常造 成非旱即涝, 在一年内先旱后涝也是常出现的[22]。按 群众的习惯分为: 春旱、夏旱、秋旱、冬旱, 以春旱出 现最为频繁。对农业生产的影响程度来看, 春旱影响最 大，受旱造成较为严重的灾旱年，春旱要占 $70 \%$ 以上; 
表 3. 云南主要生物灾害与季节变化关系

\begin{tabular}{|c|c|c|c|c|}
\hline 种类 & 易发时间 & 主要影响因子 & 特点 & 规律 \\
\hline 小麦条锈病 & 春季、秋季 & 温度 & $\begin{array}{c}\text { 辗转危害, 可在本地完成侵 } \\
\text { 染循环, 易发常发。发病区 } \\
\text { 和流行期提高 } 20-30 \mathrm{~d} \text {, 危害期 } \\
\text { 延长 } 30 \mathrm{~d}\end{array}$ & 随气温升高而加重 \\
\hline 小麦蚜虫 & 春季、秋季 & $\begin{array}{c}\text { 温度、雨量、降雨日 } \\
\text { 数、相对湿度、日照时 } \\
\text { 数 }\end{array}$ & $\begin{array}{l}\text { 大多数蚜虫适宜生长的温度 } \\
\text { 在 } 14-24^{\circ} \mathrm{C}, \text { 上限温度是 } \\
20^{\circ} \mathrm{C}, \text { 超过 } 20^{\circ} \mathrm{C}, \text { 蚜虫数量 } \\
\text { 与温度关系变为负相关趋势 }\end{array}$ & $\begin{array}{c}\text { 高温少雨天气特征下, 有利于 } \\
\text { 蚜虫的生长、发育和繁殖 } \\
\text { 春季温度与蚜虫发生的关系极 } \\
\text { 为密切。开春后气温回升, 气 } \\
\text { 候干燥, 蚜虫繁殖量大 }\end{array}$ \\
\hline 油菜蚜虫 & 春季、秋季 & 温度、降雨 & $\begin{array}{c}\text { 繁殖能力强, } 1 \text { 年能繁殖 } 10- \\
30 \text { 个世代, 世代重叠现象突 } \\
\text { 出。气温为 } 16-22^{\circ} \mathrm{C} \text { 时最适宜 } \\
\text { 蚜虫繁育, 特别是在干旱条 } \\
\text { 件下, 能引起大发生 }\end{array}$ & $\begin{array}{c}\text { 适于温暖、较干旱的气候, 春 } \\
\text { 秋两季气候温暖, 最适于他们 } \\
\text { 的生长繁殖, 所以一般春末夏 } \\
\text { 初和秋季危害严重 }\end{array}$ \\
\hline 稻飞風 & 春、夏 & $\begin{array}{c}\text { 暖冬、副热带高压、厄 } \\
\text { 尔尼诺 }\end{array}$ & $\begin{array}{l}\text { 3-5 月开始危害 } \\
\text { 5-8 月危害较大 }\end{array}$ & 影响越冬、迁飞 \\
\hline 稻瘟病 & 夏季 & 温度、湿度、光、风 & 7 月份大面积 & $\begin{array}{c}\text { 温度低、日照少、病情重; 反 } \\
\text { 之则轻 }\end{array}$ \\
\hline 玉米灰斑病 & 夏季、秋季 & 海拔 & $\begin{array}{c}6 \text { 月上旬至 } 7 \text { 月下旬始发; } 8 \\
\text { 月中旬至 } 9 \text { 月下旬迅速爆发 } \\
\text { 流行。 }\end{array}$ & $\begin{array}{c}\text { 同一品种随海拔增高病情加 } \\
\text { 重; 海拔 } 1800 \mathrm{~m} \text { 以上产量损失 } \\
\text { 最大; 海拔 } 1500-1800 \mathrm{~m} \text { 区域次 } \\
\text { 之; 海拔 } 1500 \mathrm{~m} \text { 以下区域发病 } \\
\text { 较轻。 }\end{array}$ \\
\hline 玉米螟虫 & 夏季 & 温度、湿度 & 危害期 5 月中旬至 6 月下旬 & $\begin{array}{c}\text { 适宜条件是中温高湿度环境, } \\
\text { 降雨温度适合生长发育 }\end{array}$ \\
\hline 粘虫 & 夏季 & 湿度 & $\begin{array}{c}\text { 6-7 月, 群聚性、迁飞性、杂 } \\
\text { 食性、暴食性, 扩展迅速、 } \\
\text { 危害损失重。 }\end{array}$ & $\begin{array}{c}\text { 降水多、土壤及空气湿度大, } \\
\text { 有利于发生和危害 }\end{array}$ \\
\hline 小麦白粉病 & & $\begin{array}{c}\text { 温度、湿度、雨量、日 } \\
\text { 照和气流 }\end{array}$ & $\begin{array}{l}\text { 病菌分生孢子的释放和传 } \\
\text { 播, 因地区、气候的不同而 } \\
\text { 有所差异, 孢子靠气流传播 }\end{array}$ & $\begin{array}{c}\text { 分生孢子的释放与大气湿度和 } \\
\text { 风速密切相关, 风速越大湿度 } \\
\text { 越低, 分生孢子就越容易被释 } \\
\text { 放出来, 传播也越快, 反之则 } \\
\text { 不利于分生孢子的释放和传 } \\
\text { 播。 }\end{array}$ \\
\hline
\end{tabular}


夏旱次之, 全省大面积的夏旱多是出现在夏初, 其中 $80 \%$ 以上的大旱年都是春夏连旱; 秋旱再次之, 分初秋

旱和晚秋旱两种, 以晚秋旱影响较大。晚秋旱在 1950 1991 年的 42 年头 18 个大旱年中, 其中有 6 年都出现晚 秋旱; 冬旱影响最小, 多为插花零星分布, 且出现年代 少, 灾情也仍限于 $2 、 3$ 个县。随着干旱时间的延长, 土 地荒漠化、土壤盐碱化、进一步损害，自我调节能力减 弱, 则抵抗力稳定性会继续减弱 [23]; 干旱会导致很多 捕食动物消失, 尤其是消灭鼠害和虫害的鸟类大量减少, 而适应能力较强的昆虫和啮齿类 (鼠类) 因为没有天敌 控制而大量繁衍,最终造成灾害[24]。

2009-2010 年云南遭遇旱灾，小春作物整个生育期间 持续异常高温少雨, 同期, 蚜虫重发生, 发生面积占种 植面积的 65\%。

（2）霜冻、低温导致农业生物灾害频发。

霜冻、低温等是云南仅次于旱灾的主要自然灾害。主 要是由于云南南北农业区域海拔高差悬殊, 作物四季有 收有种, 加之冷空气一年之内活动频繁, 因而易出现霜 冻、低温灾害[25]。

云南省低温霜冻灾害主要指冬季的寒潮与霜冻、3 月 前后的 “倒春寒”、以及 8 月左右的低温冷害。它是云 南农业又一严重气象灾害, 其危害程度仅次于干旱。

“倒春寒” 是指春季 2-4 月, 天气已明显变暖日平均 气温 $\geqslant 12^{\circ} \mathrm{C}$ 后, 出现的强冷空气过程, 致使气温降到 $12^{\circ} \mathrm{C}$ 后, 出现的强冷空气过程, 致使气温降到 $12^{\circ} \mathrm{C}$ 以 下。此时云南正值小麦抽穗扬花期和水稻小种期, 容易 造成小春作物较大减产和水稻烂种、烂苗, 严重影响大 春栽插进度。

霜冻也是低温引起的冻害, 对农作物的危害很大, 尤 其对蚕豆、小麦、油彩、马铃薯的影响很大。小麦在拔 节至开花期受冻害的临界气温是 $-2^{\circ} \mathrm{C}$ 左右, 蚕豆在蕾花 期受冻害的临界温度是 $-1^{\circ} \mathrm{C}$ 。此时, 一旦有冷空气入侵 或夜间出现强烈的晴空辐射散热天气时, 地面气温和植 株体温极易降至农作物临界温度以下, 致使作物受害。

8 月低温冷害频发于每年盛夏 8 月前后, 正值水稻抽 穗扬花之际, 如遇冷空气入侵, 气温持续 $3 \mathrm{~d}$ 低于 $18^{\circ} \mathrm{C}$ 、最低气温降至 $14^{\circ} \mathrm{C}$ 以下, 或连续阴冷阴雨天气, 导致水稻抽穗延迟, 空秕率增加, 稻瘟病蔓延, 粮食减 产[26]。

低温霜冻年年都有发生, 平均每年危害农作物在数万 公顷左右, 较强的两次出现在 1980 年代, 受灾面积高达 $400 \mathrm{khm} 2$ 和 $600 \mathrm{khm} 2$ 多, 并且都发生在春季的 2-3 月。

\section{（3）全球气候变暖加重云南病虫害发生。}

气候变暖将会加重对农业生产的危害程度, 特别是小 麦锈病、黏虫、草地蛽等[27]。云南同时也是全国稻飞 風、小麦条锈病和粘虫等病虫害发生、发展、传播的源 头之一[28]。气候变暖以后各种农业生物灾害出现的范 围扩大, 并向高纬度和高海拔地区延伸, 目前局限在热 带的病原和寄生组织会蔓延到亚热带甚至温带地区, 而 这些地区对于此类病原和寄生物的免疫力十分低下, 导 致蔓延加速 [29]。近年来病虫害大发生情况在云南已出
现多次, 如 2007 年、2009 年云南稻区出现大范围白背 飞風、褐飞風迁入, 迁入虫量、田间虫量等多项指标为 有历史记载以来最高年。

\section{3 灾变特点和规律}

(1) 频率高、交错叠加发生。据统计, 云南平均 2.3 年一大旱, 每年 49 县次遭受旱灾; 严重及大范围霜冻灾 害平均三年一遇, 平均每年 12 县次遭受霜冻灾害[30]。 各个季节和月份几乎均有农业气象灾害发生, 且交错叠 加发生频繁。对 $90 \%$ 山地面积的云南来说, 气象灾害往 往是多重出现。如冰雱、暴雨同时出现, 又导致涝渍、 滑坡等, 又如寒潮、霜冻接踵发生, 又如低温连阴雨诱 发病虫害等。例如, 1989 年 “2.25” 重霜冻, 导致滇中 及以北 10 个地州市小春粮食大幅度减产。这些灾害出现 的月份各月均有发生, 只是作物受灾种类不同而已。霜 冻灾害每年 18 个县次出现, 这是云南霜冻灾害的特点, 而不像它省只是旱霜和晚霜能造成灾害 [31]。

（2）季节性、地区性规律明显。霜冻灾以 11 月至次 年 4 月出现机会最多, 其中又以 1-4 月较为频繁。不同 月份的受灾地区分布是: 12 月和 1 月全年均能出现霜冻 灾害。1 月以后出现在元江以北地区, 4 月以后多出现在 滇东北和汗西北地区, 6-8 月出现在滇东北的高寒山 区, 但不是每年都有, 而是隔 $2 \sim 3$ 年有 1 次。由北方进 入云南的冷空气, 全年各月均有, 平均每月有 2 3 次。 造成霜冻、低温等灾害的强冷空气每年 6 次左右, 最多 可达 10 次左右。但由于种种原因, 目前这种周期正在缩 短, 加剧了灾害的危害[32]。

（3）区域性、突发性明显。“倒春寒” 主要发生在 滇中及以东、以北地区[33]。例如 1980 年代有名的 “86.3” 过程, 是云南历史上降雪面积最广、危害最大 的 “倒春寒” 灾害天气, 大片农作物受害。致使全省小 春作物粮食大幅度减产, 受灾严重的滇中地区几乎无 收。如 “雹走熟路” 的昭通、鹤庆等地, 老旱区宾川、 元谋, 暴雨窝子金平、江城等地。如 8 月低温冷害一般 易在哀劳山以北、以东地区出现, 是滇中、滇东地区水 稻大面积、大幅度减产的重要灾害性天气。而突发性是 云南省气象灾害的主要特征之一, 如 1989 年 2 月 25 日 的强低温霜冻, 还有局地暴雨、骤降冰霄等, 常常让人 措手不及, 危害极大。

总的特点是: 年平均气温处于下降期多低温天气, 年 降水量进入偏少期多干旱发生, 都会引发相关的生物灾 害发生蔓延。

\section{IV 防治及减灾措施探讨}

云南农业气象灾害种类繁多, 发生频繁, 是制约农业 发展的一个重要因素。云南省的农业生物灾害包括病、 虫、草、鼠、害等, 种类多、变动频繁, 技术性强, 防 御难度大[34]。农业生物灾害具有突发性、传染性和流 行性等特征, 早期监测预警和应急扑灭是有效预防控制 和铲除的关键所在, 一旦大范围蔓延则失去控制的最佳 时期, 将带来长期的灾难性后果 [35]。总体上, 云南重 大农业生物灾害的应急防控能力较低, 应急管理的组织 体系、保障体系和监督管理体系尚不健全[36]。根据云 南省植物保护与检验站的估计, 在气候变暖趋势下, 云 
南省在未来年农作物病虫草害的面积将继续加大, 强度 增强, 有持续加重趋势。这意味着农业生产将投入大量 成本用于除虫除草，这不仅将加重农业生产的负担，更 会降低农作物质量。生物灾害的发展不仅是一个简单的 发生面积的数量增长，而且在其内涵上还有质的变化， 即表现为有害生物在自然选择、生物竞争的过程中，增 加了它自身对环境的抗力或称为适应性，使人们在防治 技术方面增加了很大的难度。

（1）加大投入，依靠科技，研制和引进新技术。加大 业务经费投入，目前云南全省上下还没有真正形成抗御 重大农作物生物灾害的应急防控机制, 对突发性、暴发 性和大面积重大病虫缺乏有效、快速扑灭手段。省级财 政应设立专项资金，在全省生物灾害调查监测、应急控 制、疫情封锁防除、检疫检验等方面给予充足的经费保 障; 加强抗病虫育种,调整作物布局，加强对农业生物灾 害防治技术的研究, 研制开发绿色新型农药, 研究推广 与云南气候变化相适应的生态农业新技术，提高农业适 应生态环境新变化的能力, 将气候变化带来的不利影响 降至最低，保证农业的正常生产。

(2)加大病虫害监测预警与防控工作。加强重大病虫 害监测预警，重点防控水稻 “迁飞性” 害虫、二化螟和 稻瘟病以及玉米蚯、粘虫、马铃薯晚疫病和农区鼠害等 重大病虫害; 强化属地责任，推进综合治理、联防联 控，有效遏制重大植物疫情扩散蒀延; 强化检疫监管， 推进绿色防控与统防统治工作，提高农药监管和科学用 药水平加强对农业生物灾害防治技术的研究, 开发研制 各种高效低毒无污染的新型农药, 完善农业植保的预警 和防治基础设施, 以应对气候变化导致的病、虫、草害 可能加重的严峻挑战。

(3)深入进行气象灾害与农作物生态条件的关系研 究。由于对病虫害发生发展规律及综合治理的基础研究 重视不够,在生物灾害可持续治理上没有取得大的突破, 生产上表现出过于依赖化学农药, 导致害虫抗药性增强 和大量害虫天敌被杀伤, 使病虫害难以得到及时、有效 和可持续的控制。为有效遏制近年来农作物病虫害危害 日趋严重的态势, 大幅度增强农作物重大病虫害的防灾 减灾能力, 加强研究农作物重大病虫害发生流行的天气 气候条件, 建立并开展病虫害中长期气象预测预报业 务, 正确认识气象灾害预测在农业生态系统中的地位 [37],充分利用云南省气候资源优势、发展云南省的 “两 高一优”农业、建立生态农业等都是十分重要的。

(4) 有效提高综合防灾减灾能力。

气候变暖背景下，云南省降水量也趋于不稳定，2009 年至 2010 年云南特大干旱造成了巨大损失[38], 这铁的 事实为我们敲响了警钟。要同时兼顾科学预防与提高应 对灾害的能力[39], 加强农田水利设施建设, 更新改造 老化农业排灌工程设施 [40], 推广农业技术措施, 保护 并改善农业生态环境[41]，遏止农业生产与环境破坏的 恶性循环[42], 提高农业适应气候变化能力, 提高农业 抗御灾变的能力[431]。加强农业生物灾害风险管理, 建 立灾害风险模型[44]。将农业生物灾害纳入政策性种植 业保险范畴[45]，加大资金支持力度，扩大参保作物种 类和参保面，提高理赔率和理赔金额，充分调动农民的 积极性[46]。

\section{致谢}

本项目受国家自然科学基金 “季节转换期副热带西 风急流变化对云南降水的影响”（编号：41365007）资 助。

\section{参考文献}

[1] 张青云. 《有害生物综合治理学》[M].中国: 中国农业大学出版 社, 2007: 15-30.

[2] 曾小军, 刘芬, 周军, 黄荣华, 许晶晶, 管珊红. 江西农业气象 灾害的时空演变及其对 ENSO 特征值的响应[J]. 自然灾害学 报,2017，26 (2):177-184.

[3] 王景来, 杨子汉.云南自然灾害与减灾研究[M].云南: 云南大学出 版社, 1998: 16-21.

[4] 杨子汉, 杨光渝, 刘理化. 云南省四十年主要灾害调查（19501990）.[M].云南：云南科技出版社,1995:2-35.

[5] 云南省灾害防御协会秘书处.云南省自然灾害综述及减灾对策[J]. 地震研究,1992, 15(4):440-447.

[6] 冯秀藻,陶炳炎.农业气象学原理 [M].北京:气象出版社,1991: 86-92, 189-191,193-199.

[7] 王志伟, 张东霞, 马雅丽等. 山西省冬小麦主要病虫害气象等级 预报模型[J].中国农学通报,2010，26 (11):267-271。

[8] 龙红, 朱勇, 王学锋, 等.云南农业应对气候变化的适应性对策 分析[J].云南农业科技,2010（4）:6-9.

[9] 王宁, 胡杏, 曲瑞伟.云南农业灾害的主要类型及其对策初探 [J]. 云南农业大学学报,2012，6 (6):11-15.

[10] 杨光宇, 王景来, 杨子汉.云南省自然灾害成因探讨及减灾对策 [J].自然灾害学报,1994，3(4): 95-102.

[11] 张建琴.云南气候变化对云南农业生产的影响以及对策. [J]. 农业与 技术，2012，32(5):152.

[12] 李乡旺,胡志浩, 胡晓立, 等.云南主要外来入侵植物初步研究 [J]. 西 南林学院学报,2007, 82 (6):5-10

[13] 黄中艳, 朱勇.1954-2007 年云南农业气候变化研究 [J]. 气 象,2009, 35 (2):111-118.

[14] 韩湘玲,曲曼丽. 作物生态学 [M]. 北京:气象出版社,1991, 27-39, 42-46,51-63, 67-70.

[15] 龙红.气候变暖对云南省冬作物影响[J].云南农业科技, 2006 (3).

[16] 叶彩玲, 霍治国, 丁胜利, 施生锦, 王素艳, 侯婷婷. 农作物病虫害气 象环境成因研究进展[J]. 自然灾害学报, 2005, 14(1): 90-97.

[17] 吴兆峰, 钟宝太.农作物病虫害气象环境成因研究进展 [J].民营科 技,2013(5): 90-97.

[18] 王 丽, 霍治国, 张 蕾, 姜玉英, 肖晶晶, 卢小风. 气候变化对中 国农作物病害发生的影响[J]. 生态学杂志,2012，31(7): 1673-1684

[19] 薛昌颖, 马志红, 胡程达. 近 40a 黄淮海地区夏玉米生长季干旱 时空特征分析[J].自然灾害学报,2016，25(2): 1-14.

[20] 张万诚, 郑建萌, 任菊章. 云南极端气候干旱的特征分析 [J]. 灾害 学,2013, 28(1): 59-64.

[21] Rongfang Li,Lijun Cheng,Yongsheng Dingetf.An Operational Drought Risk Management Framework Based on stream-flow Intelligent Internet control[J].Journal of Risk Analysis and Crisis Response, Vol. 3, No. 1 (May 2013), 34-43.

[22] 王连喜, 缪丞, 李琪, 薛兴权, 孙晓宇, 吴东丽. 陕西省冬小麦干 旱时空变化特征分析[J].自然灾害学报,2016，25(2):35-42.

[23] 解明恩, 程建刚. 云南气象灾害特征及成因分析 [J]. 地理科 学,2004, 24(6): 721-726.

[24] ]Xiaodong Wang.The Analysis on the Effecting Factor of Drought Disease in Qingyang, Gansu[J].Journal of Risk Analysis and Crisis Response, Vol. 6, No. 2 (July 2016),103-107.

[25] 鲍文.云南地区农业气象灾害及防灾减灾能力构建研究[J].沈阳农 业大学学报 (社会科学版) ,2011 (2):49-50.

[26] 尤卫红,傅抱璞, 林振山. 云南近百年气温变化与 8 月低温冷害天 气[J].高原气象, 1997, 16(1): 63-72.

[27] 霍治国, 李茂松, 王 丽, 温泉沛, 肖晶晶, 黄大鹏, 王春艳. 气 候变暖对中国农作物病虫害的影响 [J]. 中国农业科学, 2012, 45(10):1926-1934.

[28] 姚愚, 李晓鹏, 闰丽萍, 等. 近 44 年云南年平均气温的时空变化 特征[J].气象, 2006, 32(10): 81-87.

[29] 张国庆.气候变化对生物灾害发生的影响及对策[J].现代农业科 技,2011 (1):318-321. 
[30] 王宇. 云南省农业气候资源及区划 [M].北京:气象出版社,1990: 1012.

[31] 何娇楠, 李运刚, 李 雪, 黄江成. 云南省干旱灾害风险评估[J].自然 灾害学报,2016，25(5): 37-45.

[32] 吉文娟,张加言,胡雪琼.云南小春作物蚜虫发生发展气象条件及防 治[J].云南农业科技,1993 (3):10-13.

[33] 张云瑾,尹红梅.云南 70 90 年代倒春寒的天气气候特征[J].云南 大学学报(自然科学版), 1999(05):370-373.

[34] 袁晓仙.自然与人为:环境史视野下的云南生物灾害及应对研究 [J]. 文山学院报,2017,30(04):21-27.

[35] 张国庆.生物灾害管理理念研究与生物灾害精确管理[J].现代农业 科技.2011(03):20-23+26.

[36] 杨银波，杨子汉，杨光宇.云南自然灾害综述及减灾对策[J].地震 研究.1992(04):440-447.

[37] Guo Shujun.The Meteorological Disaster Risk Assessment Based on the Diffusion Mechanism[J].Journal of Risk Analysis and Crisis Response, Vol. 2, No. 2 (August 2012), 124-130.

[38] 陶云, 张万诚, 段长春等.云南 2009-2012 年 4 年连旱的气候成因 研究[J].云南大学学报（自然科学版）2014, 36（06）:866-874.

[39] 王德兴, 柳建仪.值得重视的生物灾害研究[J].陕西师范大学继续 教育学报 2002（03）:117-120.

[40] 鲍文.云南地区农业气象灾害及防灾减灾能力构建研究[J].沈阳农 业大学学报(社会科学版), 2012,14(06):643-647.
[41] Jingjing Xiao,Zhiguo Huo,Dapeng Huang etf.Meteorological Grading Indexes of Water saving Irrigation for Corn[J].Journal of Risk Analysis and Crisis Response, Vol. 3, No. 2 (August 2013), 95-10.

[42] Sijian Zhao,Qiao Zhang.Risk Assessment of Crops Induced by Flood in the Three Northeastern Provinces of China on Small Space-andTime Scales [J].Journal of Risk Analysis and Crisis Response, Vol. 2, No. 3 (November 2012), 201-208.

[43] 秦剑,余凌翔,谢在永.《云南气象灾害史料及评估咨询系统》 [J].气 象,2001(08):39.

[44] 刘红晋. 云南历史旱灾及防控措施研究 [D]. 西北农林科技大 学,2012.

[45] Kaicheng Xing ,Shujun Guo. Study on Meteorological Service Policy for Agricultural Insurance in Hebei Province under the Background of Climate Change[J]. Journal of Risk Analysis and Crisis Response Vol. 9(1), March (2019), pp. 36 - 42.

[46] 杨文杰.论政府灾前预防的责任--以预防云南自然灾害为例 [J].云 南师范大学学报（哲学社会科学版）,2011，43(6): 134-137. 